\title{
ANALYSIS OF MSME ACTORS' BEHAVIOR IN PREPARING FINANCIAL STATEMENTS WITH MODIFIED THEORY OF PLANNED BEHAVIOR
}

\author{
Husnunnida Maharani \\ Departemen Akuntansi, Universitas Internasional Semen Indonesia, Jl. Veteran, Gresik \\ husnunnida.maharani@uisi.ac.id
}

Received: January, 2019

Reviewed: April, 2019

Accepted: April, 2019

\section{ABSTRACT}

This research aimed to examine factors that can increase the MSME actors' interest in preparing financial statements dan relate this interest to the MSME actors' actual behavior of preparing financial statements. This research modified the Theory of Planned Behavior (TPB) by adding 'self-efficacy' construct. This research employed a survey method by using questionnaires to collect the data from the research samples of MSME actors assisted by PT. Semen Indonesia (Persero) Tbk. The samples selected were those who had prepared financial statements, amounted to 100 respondents. Moreover, the researcher used a Partial Least Square (PLS) in the data analysis. The results showed that 'interest' construct positively affected the MSME actors' behavior of preparing financial statements. Attitudes, subjective norms, behavioral control, and self- efficacy also had a positive effect on the MSME actors' interest in preparing financial statements. The implications of the results of this research can be used as evaluation materials by the Partnership and Environmental Development Programs of PT. Semen Indonesia (Persero) Tbk. to create more MSME actors with the capability of preparing financial statements. This capability can facilitate the process of monitoring and evaluating the performance of MSMEs by providing the required factors through training and development programs.

Keywords: Behavior, MSMEs, Financial Statements

How to cite: Maharani, H. (2019). Analysis of MSME Actors' Behavior in Preparing Financial Statements with Modified Theory of Planned Behavior. Akrual: Jurnal Akuntansi. 10 (2): 135-144.doi: http://dx.doi.org/10.26740/jaj.v10n2.p135-144

\section{INTRODUCTION}

Business entities in Indonesia are grouped into large businesses and Micro, Small, and Medium Enterprises (MSMEs). According to Law Number 20 of 2008, MSME is a business entity with a turnover of less than IDR 300,000,000,(three hundred million rupiah) per year. MSME actors play a considerable role in building the Indonesian economy. However, developing a good performance of MSMEs is not easy. One way to measure MSME performance is by looking at the financial statements held.
This research discusses the issue about the MSME actors' behavior in preparing financial statements. Behavior is a concrete action or activity carried out by individuals (Hartono, 2007: 117). A financial statement is a means of communicating key financial information to parties outside the company (Kieso, 2007: 2). Thus, the MSME actors' behavior of preparing financial statements refers to a concrete action taken by MSME actors in the preparation of financial statements. 
AKRUAL: Jurnal Akuntansi, volume 10, issue 2, April 2019 (135-144)

The often encountered problem related to MSMEs is the presence of MSME actors who have not been able to prepare financial statements correctly. Most MSMEs have not carried out maximum accounting practices in running their businesses (Pinasti, 2007; Rusdiantoro and Siregar, 2012). In general, the incapability of MSME actors to prepare financial statements correctly is due to their low understanding of accounting, their bustles that make them have no time to record, and their assumption that preparing financial statements is not important, without which their businesses can still run and earn profits.

Several studies have shown that the cause of failure of an implementation process is more on the behavioral aspect (Hartono, 2007: 1). Someone will take action if he has the interest within himself. Interest is a desire for someone to do a behavior (Hartono, 2007: 116). Although behavior can be predicted through someone's interest, information of the reasons for his behavior cannot be directly determined (Ajzen, 1991). Therefore, this research focused on analyzing the reasons for the emergence of interest and identifying the effect of interest on the behavior of MSME actors in preparing financial statements.

This research involved the object of MSME actors assisted by PT. Semen Indonesia (Persero) Tbk who had recorded financial statements. The object selection was under the consideration that the Partnership Program of PT. Semen Indonesia (Persero) Tbk had 136 difficulties in carrying out the process of monitoring and evaluating the MSME performance because still many of them could not yet prepare financial statements. Financial statements are a form of MSME actors' accountability to investors or capital providers. Therefore, financial statements are highly useful for assessing the business performance of MSMEs. One way to achieve a good business performance is by keeping business records, financial management, and credit management (Kementrian Pendidikan Nasional 2010: 9).

Previous studies regarding the preparation of MSME financial statements were mostly aimed only at identifying factors influencing the MSME actors' interest to make financial statements. The studies do not discuss the MSME actors' actual behavior of preparing financial statements. Differently, this research modified the Theory of Planned Behavior by adding an independent variable, namely selfefficacy. The construct of self-confidence is associated with behavioral interest because selfefficacy influences emotional responses (Bandura, 1991).

\section{LITERATURE REVIEW The Behavior of Preparing Financial Statements}

Behavior is a concrete action or activity carried out by individuals (Hartono, 2007: 25). One's action in using information technology is a form of behavior. Ajzen (1988) explained that behavior carried out by humans is divided into two types, namely volitional behavior and 
mandatory behavior. Volitional behavior is an activity carried out by individuals at their desires. If an individual does not want to do it, he can refuse it. Meanwhile, mandatory behavior is an activity carried out due to demands or obligations. Individuals in this research are MSME actors who prepared financial statements. A financial statement is a means of communicating key financial information to parties outside the company (Kieso, 2007: 2). MSME actors prepare financial statements to show their financial performance as a form of accountability after receiving additional capital from PT. Semen Indonesia (Persero) Tbk.

\section{Theory of Planned Behavior}

The Theory of Planned Behavior (TPB) is the development of the Theory of Reasoned Action (TRA) based on the variables of attitudes, subjective norms, and behavioral control. $\mathrm{Lu}$ et al. (2010) explained that Ajzen (1985) modified TRA and proposed TPB to explain human behavior patterns. TPB shows that interest is influenced by attitudes, subjective norms, and behavioral control. Moreover, Ajzen (1985) added a construct of behavioral control in TPB to control individual behavior that is limited by his shortcomings and lack of resources used to carry out his behavior. TPB assumes that not all behavior is under full control, so the concept of behavioral control is added.

\section{RESEARCH METHODS Population and Samples}

This research population was MSMEs registered in the Partnership and Environmental Development Programs of PT. Semen Indonesia (Persero) Tbk. This research chose MSME actors assisted by PT. Semen Indonesia (Persero) as the research object since the Partnership Program found it difficult to assess the MSME performance after providing additional business capital. The difficulties were due to the incapability of most MSME actors in preparing financial statements. The MSME actors taken as the research samples were those who were able to prepare financial statements.

\section{Data Collection Method}

Data of this research were collected using a survey method. Survey method is a method of collecting primary data using written questions (Indriantoro and Supomo, 1999). The data used in this research were primary data obtained from MSME actors through questionnaires.

\section{Data Analysis Technique}

This research hypothesis testing employed a statistical method of Partial Least Square (PLS) with SmartPLS 3 program. This research aimed to identify the main determinant variables and develop the TPB theory.

\section{Research Model}

This research combined several constructs to identify the MSME actors' behavior of preparing financial statements. This research is a development of the TPB model. The constructs used in this research consisted of attitudes, subjective norms, behavioral control, selfefficacy, interest and behavior. 
Here is the research model framework:

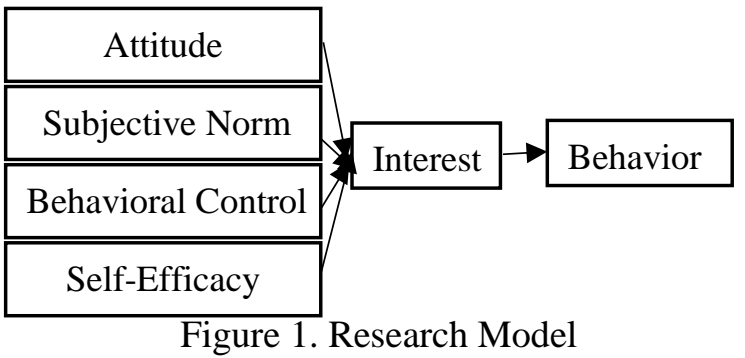

The Effect of Attitudes on Interest

Ajzen (1991) asserted that attitudes refer to the degree to which a person has a favorable or unfavorable evaluation of the behavior of interest. The attitudes in this research were the MSME actors' feelings of like or dislike towards the preparation of financial statements, based on the benefits obtained when using it. There are several previous studies which examined the significant effect of attitudes on the interest in using information systems, including Davis et al. (1989), Chang et al. (2005), and Lu et al. (2010). Chang et al. (2005) and Lu et al. (2010) argued that attitudes affect the interest to use information systems. Based on the description above, the first hypothesis formulated in this research is as follows:

\section{$H_{1}$ : Attitudes have a positive effect on the MSME actors' interest in preparing financial statements}

\section{The Effect of Subjective Norms on Interest}

Hartono (2007: 42) described that subjective norms are one's perceptions of others' beliefs which will influence his interest to do or not to do the behavior under consideration. Subjective norms in this research refer to support from other people around the MSME actors to prepare financial statements. David et al. (1989), Taylor 138 and Todd (1995), Yi et al. (2006), and Lu et al. (2010) found that 'subjective norm' construct affects 'interest' construct. If other people believe that doing a behavior is a positive thing and MSME actors want to use this perception as a consideration, subjective norms can affect the MSME actors' interest in preparing financial statements. Based on the explanation above, the second hypothesis proposed in this research is as follows:

\section{$\mathrm{H}_{2}$ : Subjective norms have a positive effect on the MSME actors' interest in preparing financial statements}

\section{The Effect of Behavioral Control on Interest}

According to Ajzen (1991), behavioral control is the perceived ease or difficulty in carrying out a behavior. The behavioral control in this research was the ease or difficulty experienced by the MSME actors when preparing financial statements. The results of $\mathrm{Lu}$ et al. (2010) study suggest that behavioral control affects user interest. These results are consistent with George (2014) examining the consumer purchase interest through the internet using TPB. The third hypothesis formulated in this research states is:

$\mathrm{H}_{3}$ : Behavioral control has a positive effect on the MSME actors' interest in preparing financial statements.

\section{The Effect of Self-Efficacy on Interest}

Self-efficacy refers to one's belief in his ability to accomplish particular tasks and face obstacles with his actions and resources (Sniehotta et al., 2005). Self-efficacy influences behavioral interest (Fu et al., 2006; Lam, et al. 2007; Chen 
et al., 2013). The results of these three studies also denote that self-efficacy affects interest. Based on this explanation, the fourth hypothesis proposed in this research is as follows:

$H_{4}$ : Self-efficacy has a positive effect on the MSME actors' interest in preparing financial statements.

\section{The Effect of Interest on Behavior}

Interest indicates an individual's readiness to carry out specific behavior and is assumed as a direct antecedent of behavior ( $\mathrm{Lu}$ et al., 2010). Interest in this research refers to the intention, desire, and readiness of MSME actors to prepare financial statements. Lu et al. (2010) proved that 'interest' construct has a positive effect on behavior, supporting Fishbein and Ajzen (2010) statement that interest indicates how hard people are willing to try or how much effort they are going to make to perform a behavior. In this regard, the researcher formulated the fifth hypothesis as follows:

H$_{5}$ : Interest has a positive effect on the MSME actors' behavior in preparing financial statements

\section{ANALYSIS AND DISCUSSION Questionnaire Return Rate}

Respondents in this research were MSME actors assisted by PT. Semen Indonesia (Persero) Tbk. who were able to prepare financial statements. There were 120 questionnaires distributed in this research yet there were only 114 questionnaires successfully returned. After examining the collected questionnaires, the researcher found that there were nine (9) questionnaires incompletely filled and five (5) questionnaires inconsistently filled. Thus, there were only 100 questionnaires $(83.3 \%)$ that could be processed further. The following table presents the number of samples and the questionnaire return rate.

Table 1. Questionnaire Return Rate

\begin{tabular}{lcc}
\hline \multicolumn{1}{c}{ Description } & Number & Percentage \\
\hline Distributed questionnaires & 120 & $100 \%$ \\
Unreturned questionnaires & $\underline{(6)}$ & $\underline{5 \%}$ \\
Returned questionnaires & 114 & $95 \%$ \\
Incomplete questionnaires & $(9)$ & $7,5 \%$ \\
Inconsistent questionnaires & $(5)$ & $4,1 \%$ \\
Processed questionnaires & 100 & $83,3 \%$ \\
\hline
\end{tabular}

Source: personal processing

\section{Validity Test}

Based on the parameter in the convergent validity test, the AVE value should be $>0.5$. As seen in Table 2 below, the AVE values of all constructs in this research were $>0.5$.

\begin{tabular}{lc}
\multicolumn{2}{c}{ Table 2. AVE Values } \\
\hline \multicolumn{1}{c}{ Constructs } & $\begin{array}{c}\text { AVE } \\
\text { Values }\end{array}$ \\
\hline Behavior & 0.641 \\
Interest & 0.578 \\
Attitude & 0.770 \\
Subjective Norm & 0.646 \\
Behavioral Control & 0.738 \\
Self-Efficacy & 0.602 \\
\hline
\end{tabular}

Source: personal processing

The constructs from the highest AVE value to the lowest were sequentially Attitude (0.770), Behavioral Control (0.738), Subjective Norm (0.649), Behavior (0.641), Self-Efficacy (0.602), and Interest (0.578). Based on the results above, the constructs and indicators in this research met the validity test.

\section{Reliability Test}

The two parameters used to assess reliability are Cronbach's Alpha of > 0.6 and composite 
AKRUAL: Jurnal Akuntansi, volume 10, issue 2, April 2019 (135-144)

reliability of $>0.7$. The following table shows the Cronbach's Alpha and composite reliability values obtained in this research:

Table 3. Cronbach's Alpha and Composite Reliability Values

\begin{tabular}{lcc}
\hline Constructs & $\begin{array}{c}\text { Cronbach's } \\
\text { Alpha }\end{array}$ & $\begin{array}{c}\text { Composite } \\
\text { Reliability }\end{array}$ \\
\hline Behavior & 0.743 & 0.842 \\
Interest & 0.816 & 0.872 \\
Attitude & 0.703 & 0.870 \\
Subjective Norm & 0.727 & 0.846 \\
Behavioral Control & 0.823 & 0.894 \\
Self-Efficacy & 0.773 & 0.856 \\
\hline
\end{tabular}

Source: personal processing

Table 3 describes that all the Cronbach's alpha values reached $>0.6$ and the composite reliability values obtained $>0.7$. The table above indicates that the measurement data and results in this research were reliable. In conclusion, all constructs and indicators used in this research were both valid and reliable.

\section{Hypothesis Testing}

The parameter used in hypothesis testing is path coefficient values. Path coefficient values show the level of significance in testing hypotheses. The parameter for the t-statistics value must be > 1.64. A hypothesis will be accepted if the $t-$ statistics value is $>1.64$ and rejected if the tstatistics value is $<1.64$. Table 4 below presents the path coefficient results in this research:

Table 4. Path Coefficient Results

\begin{tabular}{cccc}
\hline Hypothesis & $\begin{array}{c}\text { T- } \\
\text { Statistics }\end{array}$ & P-Value & Description \\
\hline H1 & 2.263 & 0.024 & Accepted \\
H2 & 2.190 & 0.029 & Accepted \\
H3 & 4.353 & 0.000 & Accepted \\
H4 & 2.093 & 0.037 & Accepted \\
H5 & 17.898 & 0.000 & Accepted \\
\hline
\end{tabular}

Source: personal processing

\section{First Hypothesis (H1) Testing}

The first hypothesis in this research states that attitudes have a positive effect on the MSME actors' interest in preparing financial statements. The test results showed a t-statistic value of 2.263 ( $>$ the $t_{\text {table }}$ value of 1.64) with a p-value of 0.024. Based on these results, the first hypothesis was accepted. These results support previous studies by Chang et al. (2005) and Lu et al. (2010). The results of both previous studies suggest that attitudes positively influence interest. MSME actors' attitudes in preparing financial statements show the level of good or poor evaluation of financial statements. The better the MSME actors' attitudes are, the greater their interest in preparing financial statements will be.

\section{Second Hypothesis (H2) Testing}

The second hypothesis in this research states that subjective norms have a positive effect on the MSME actors' interest in preparing financial statements. The test results showed a t-statistics

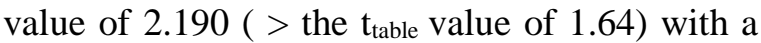
$\mathrm{p}$-value of 0.029 . These results indicate that subjective norms positively affected the MSME actors' interest in preparing financial statements. Thus, the second hypothesis was accepted. These results are consistent with previous studies by $\mathrm{Lu}$ et al. (2010), Venkatesh and Davis (2000), Yi et al. (2006), and Lam, Cho, and Qu (2007) which also found that 'subjective norm' construct positively influences the interest in using information technology. The results of this research indicate that the more positive the 
information provided regarding the preparation of financial statements is, the more the MSME actors' interest in preparing financial statements will be. The willingness of MSME actors to prepare financial statements can be influenced by the social pressure from their superiors, families, or coworkers.

\section{Third Hypothesis (H3) Testing}

The third hypothesis in this research states that behavioral control has a positive effect on the MSME actors' interest in preparing financial statements. The test results showed a t-statistics value of 4.353 (> the $t_{\text {table }}$ of 1.64) with a p-value of 0.000 . These results indicate that behavioral control positively affected the MSME actors' interest in preparing financial statements. Thus, the third hypothesis was accepted. This research strengthens the previous study by $\mathrm{Lu}$ et al. (2010) proving that behavioral control has a positive effect on interest. If MSME actors are convinced that they can control their behavior in preparing financial statements and have the necessary resources, they will more likely intend to construct financial statements.

\section{Fourth Hypothesis (H4) Testing}

The fourth hypothesis in this research states that self-efficacy has a positive effect on the MSME actors' interest in preparing financial statements. The test results showed that the t-statistics value reached 2.093 (> the $t_{\text {table }}$ value of 1.64) with a pvalue of 0.037 . That is, self-efficacy positively affected the MSME actors' interest in preparing financial statements. Thus, the fourth hypothesis was accepted. The MSME actors' self-efficacy to prepare financial statements is greatly important to increase their interest in preparing financial statements. The higher the MSME actors' self-efficacy is to prepare financial statements, the higher their interest in preparing financial statements will be. This research supports previous studies by Fu et al. (2006), Lam, Cho, and Qu (2007), and Chen et al. (2013). The results of these three studies suggest that self-efficacy influences interest.

\section{Fifth Hypothesis (H5) Testing}

The fifth hypothesis in this research states that interest has a positive effect on the MSME actors' behavior of preparing financial statements. The test results showed that the tstatistics value reached 17.898 ( $>$ the $t_{\text {table }}$ value of 1.64) with a p-value of 0.000 . These results indicate that interest positively affected the MSME actors' behavior of preparing financial statements. Thus, the fifth hypothesis was accepted. That is, the stronger intention of the MSME actors to prepare financial statements will more encourage them to do it. These results are consistent with Ajzen (1991) finding that interest has a positive effect on the behavior of using information technology. Several other studies that reinforce these empirical results are those conducted by Venkatesh and Davis (2000) and $\mathrm{Lu}$ et al. (2010). Both also proved that 'interest' construct positively influences behavior.

\section{CONCLUSIONS}

The results of this research conclude that the 
AKRUAL: Jurnal Akuntansi, volume 10, issue 2, April 2019 (135-144)

MSME actors' behavior of preparing financial statements depends on their interest in performing it. The stronger their interest is in preparing financial statements, the more likely they will perform the behavior. This research suggests that interest is the main factor influencing the behavior of preparing financial statements. Interest can influence the behavior of preparing financial statements since MSME actors believe that they can improve and continue the preparation of financial statements, make financial statements as a top priority, and recommend to prepare financial statements.

The interest in preparing financial statements is influenced by attitudes, subjective norms, behavioral control, and self-efficacy. The better the MSME actors' attitudes are, the stronger their interest in preparing financial statements will be. Besides, the more positive information provided regarding the preparation of financial statements can more attract the MSME actors' interest in preparing financial statements. Similarly, the higher the MSME actors' ability to control the preparation of financial statements, the more likely they will be interested in preparing financial statements. The higher the MSME actors' self-efficacy in the preparation of financial statements is, the stronger their interest in preparing financial statements will be. Lastly, the stronger interest of MSME actors in preparing financial statements will further encourage them to do it.

The limitations of this study are related to the sample selection method. Researcher using 142 the convenience sampling method. Based on this, researchers cannot generalize the results of this study. Researcher's suggestion for the topic and the same subject of study is to reconsider the method of selecting the sample used so that the results of the study can be generalized.

\section{ACKNOWLEDGMENTS}

The research is fully funded by Universitas Internasional Semen Indonesia with the Research Contract No:08/KP.01/11-01/04.18. The author expresses gratitude and appreciation to Universitas Internasional Semen Indonesia for the opportunity and trust.

\section{REFERENCES}

Ajzen, I. (1985). From intentions to actions: A theory of planned behavior. Heidelberg: Springer.

Ajzen, I. (1988). Attitudes, Personality, and Behavior. Chicago: IL: Dorsey.

Ajzen, I. (1991). The Theory of Planned Behavior. Organizational Behavior and Human Decision Process, 50, 179-211.

Alleyne, P \& Phillips, K. (2011). Exploring Academic Dishonesty Among University Students in Barbados: An Estension to the Theory of Planned Behavior. Journal of Academic Ethics, 9, 323-338.

Bandura, A. (1999). Social Cognitive Theory: An Agentic Perspective. Journal of Business Ethics, 61, 165-181.

Chang, I. C., et al. (2005). An Empirical Study on The Impact of Quality Antecedents on Tax Payers' Acceptance of Internet Tax Filing Systems. Government Information Quarterly, 22, 389-410.

Davis, F. D., Bagozzi R. P., \& Warshaw, P. R. (1989). User Acceptance of Computer Technology: A Comparison of Two Theoretical Models. ABI/Inform Global. Management Science, 982. 
Fishbein, M. \& Ajzen, I. (2010) Predicting and Changing Behavior: The Reasoned Action Approach. Psychology Press, New York.

Kementrian Pendidikan Nasional. (2010). Modul Manajemen Usaha Kecil [Electronic Version].

Fu, J. R., Farn, C. K., \& Chao, W. P. (2006). Acceptance of Electronic Tax Filing: A Study of Taxpayer Intentions. Information and Management, 43, 109-126.

George, J. F. (2004). The Theory of Planned Behavior and Internet Purchasing. Internet Research, 14.

Hartono, H. M. (2007). Sistem Informasi Keperilakuan. Yogyakarta: CV. Andi Offset.

Indriantoro, N. \& Supomo, B. (1999). Metodologi Penelitian Bisnis untuk Akuntansi dan Manajemen. Edisi 1. Cetakan Pertama BPFE. Yogyakarta.

Karami, M. (2006). Factor Influencing Adopting Online Ticketing. Lulea University of Technology.

Kieso, W. (2007). Akuntansi Intermediate. Jakarta: Penerbit Erlangga.

Lam, T., Cho, V., \& Qu, H. (2007). A Study Of Hotel Employee Behavioral Intentions Toward Adoption Of Information Technology. International Journal of Hospitality Management, 26, 9-65.

Lu, C. T., Huang, S. Y., \& Lo, P. Y. (2010). An Empirical Study of On-Line Tax Filling Acceptance Model: Integrating TAM and TPB. African Journal of Business Management, 4, 800-810.

Pinasti, M. (2007). Pengaruh Penyelenggaraan dan Penggunaan Informasi Akuntansi Terhadap Persepsi Pengusaha Kecil atas Informasi Akuntansi: Suatu Riset Eksperimen. Simposium Nasional Akuntansi X.

Rusdiantoro, R., \& Siregar, S.V. (2012). Kualitas Laporan Keuangan UMKM serta Prospek Implementasi SAK ETAP. Jurnal Akuntansi dan Keuangan Indonesia, 9.
Sniehotta, F., Scholz, U., \& Schwarzer, R. (2005). Bridging the Intention-Behavior Gap: Planning, Self Efficacy, and Action Control in the Adoption and Maintenance of Physical Exercise. Psychology and Health Journal, 20, 143-160.

Taylor., \& Todd, P. A. (1995). Understanding Information Technology Usage: A Test of Competing Models. Information Systems Research, Vol 6.

Venkatesh, V., \& Fred D. D. (2000). A Theoretical Extension Of The Technology Acceptance Model: Four Longitudinal Field Studies. ABI / Inform Global. Management Science, 186.

Yi, M. Y. (2006). Understanding Information Technology Acceptance By Individual Professionals: Toward An Integrative View. Information and Management, 43, 350-363. 
AKRUAL: Jurnal Akuntansi, volume 10, issue 2, April 2019 (135-144)

This page is intentionally left blank 